\title{
PENGARUH METODE PEMBELAJARAN DAN TINGKAT MOTOR EDUCABILITY (ME) TERHADAP KETERAMPILAN DASAR SMASH KEDENG DALAM PERMAINAN SEPAK TAKRAW DI SMPN 4 KUBUTAMBAHAN
}

\author{
I Ketut Semarayasa ${ }^{1}$, Gde Eka Budi Darmawan ${ }^{2}$, I Nyoman Sudarmada ${ }^{3}$ \\ 1,3 Jurusan Pendidikan Jasmani Kesehatan dan Rekreasi, Fakultas Olahraga dan Kesehatan \\ Universitas Pendidikan Ganesha, Singaraja, Indonesia \\ e-mail: iketutsemarayasa@yahoo.com, AdetaBudiDarmawan@yahoo.com, \\ inyomansudarmada@yahoo.co.id
}

\begin{abstract}
Abstrak
Penelitian ini bertujuan untuk: 1) mendapatkan informasi tentang guru-guru SD di kota Singaraja memilih atau menggunakan materi pelajaran sesuai dengan konteks, lingkungan, setting siswa, atau materi pelajaran yang berbasis local content; 2) mendapatkan informasi pada bidang studi apa saja guru-guru SD di kota Singaraja telah memilih atau menggunakan materi pelajaran sesuai dengan konteks, lingkungan, setting siswa, atau materi pelajaran yang berbasis local content; 3) mengetahui bagaimana tingkat kemampuan guru-guru SD di kota Singaraja dalam memilih, atau menggunakan materi pelajaran sesuai dengan konteks, lingkungan, setting siswa atau materi pelajaran yang berbasis local content. Penelitian ini dirancang dalam bentuk penelitian ex post facto, yang bersifat kualitatif. Data dikumpulkan dengan teknik koleksi dokumen dan dengan cara multistage stratified random sampling. Selanjutnya data dianalisis secara deskriptif dan kualitatif. Hasil penelitian ini menunjukkan: 1) RPP guru-guru SD di Kota Singaraja yang mengandung materi pelajaran berbasis local content berjumlah 302 buah $(76,46 \%)$. RPP guru-guru SD di Kota Singaraja yang tidak mengandung materi yang berbasis local content adalah 93 buah $(23,54 \%)$; 2) bidang studi Bahasa Bali secara keseluruhan menggunakan materi pelajaran yang berbasis local content. Bidang studi Bahasa Indonesia hanya menggunakan:77,57\%, Pendidikan Kewarganegaraan: 72,55\%, IImu Pengetahuan Alam: 65,79\%, Matematika: $84,09 \%$, IImu Pengetahuan Sosial: $77,27 \%$, Seni Budaya dan Keterampilan: 90\%, dan Agama Hindu: 83,33\%.; 3) Jumlah RPP yang berada pada kategri sangat cocok adalah 163 buah (53,44\%). Jumlah RPP yang berada pada kategori cukup cocok adalah 142 buah (46,56\%). Tak satu pun RPP ada pada tingkat kategori tidak cocok. Disarankan agar, para guru SD di kota Singaraja memilih dan menggunakan materi pelajaran berbasis local content untuk mendukung pembelajaran bermakna.
\end{abstract}

Kata kunci: rencana pembelajaran, local content, sekolah dasar

\begin{abstract}
This is an experimental study aiming at: 1) investigating whether there is any significant difference in students' sepak takraw kedeng skill techniques between students who are taught by the part practice method and those who are taught by whole practice method, 2) finding out whether there is any significant difference in sepak takraw kedeng skill techniques between high ME learners and low ME learners, 3) investigating whether there is any interaction between the implementation of teaching methods and students' level of ME on students' basic skill techniques of sepak takraw. 124 male students of Yunior Scholl 4 Kubutambahan became the population of this study. By implementing proportional random sampling technique, 40 male students then was selected as the sample of the study. Having analyzing the data, it was found that 1) there is a significant difference in students' sepak takraw kedeng skill techniques between the students who were taught by part practice method and those who were taught by whole practice method, 2) there is a significant difference in sepak takraw kedeng skill techniques between high ME learners
\end{abstract}


and low ME learners, 3) there is an interaction between the implementation of teaching method and students' level of ME on students' kedeng skill techniques of sepak takraw.

Key words: Teaching method, ME, and kedeng.

\section{PENDAHULUAN}

Berbagai penelitian telah banyak dilakukan guna mengembangkan sistem pembelajaran yang efektif di metode pendidikan, tetapi semua itu belum dapat menuntaskan masalah, bahkan masalah baru terus muncul silih berganti seiring dengan perkembangan dunia pendidikan. Penyebab timbulnya masalah diantaranya adalah terjadinya ketidakseimbangan antara kemajuan bidang iptek pendidikan dengan peningkatan kulitas sumber daya manusianya, apalagi di Sekolah Menengah Pertama, dimana tingkat heterogenitas siswanya sangat tinggi bila dilihat dari latar belakang ekonomi, adat istiadat, budaya, prestasi akademik, motivasi, hobi, keterampilan (skill) dan bakat.

Keterampilan, hobi dan bakat khususnya menyangkut tugas gerak dalam proses pendidikan jasmani, olah dan kesehatan (Penjasorkes), masalahnya cukup kompleks yang menjadi penghambat pencapaian tujuan kurikulum Penjasorkes.

Salah satunya adalah usaha meningkatkan penguasaan keterampilan siswa sekolah Menengah Pertama dalam berbagai cabang olahraga yang ada dalam kurikulum, karena salah satu tujuan khusus pendidikan jasmani (Husdarta, 2009: 9).

Permainan sepak takraw di daerah Bali mempunyai nilai strategis, sebab permainan ini mulai digemari oleh masyarakat dengan mulai berdiri club-club atau perkumpulan-perkumpulan sepak takraw di setiap kabupaten dengan sarana dan prasarana yang cukup memadai. Sedangkan untuk di Kabupaten Buleleng sendiri sudah mulai berkembang dengan adanya beberapa klub sepak takraw. Permainan sepak takraw adalah salah satu materi pelajaran pilihan yang di dapatkan Siswa Sekolah Pertama. Pembinaan sudah dilakukan dengan baik, akan tetapi penguasaan keterampilan dasar sepak takraw yaitu smash terutama smash kedeng yang dikuasai oleh siswa selama dalam proses pembelajaran belum menunjukkan kemampuan dan keterampilan yang diharapkan. Hal ini dapat di lihat dari hasil nilai semester dari guru penjasorkes untuk nilai sepak takraw terutama nilai smash kedeng-nya jauh dari nilai standarnya, disamping itu SMP N 4 Singaraja yang mewakili Buleleng untuk Porseni Pelajar Bali untuk cabang sepak takraw masih masih jauh dari yang diharapkan, hal ini dikarenakan masih kurangnya penguasaan smash, terutama smash kedeng-nya. Hal ini mungkin disebabkan oleh waktu latihan yang terbatas, fasililas yang kurang memadai, metode pengajaran yang kurang efektif, kemampuan beradaptasi terhadap penguasaan keterampilan baru (ME) rendah, faktor lingkungan belajar yang kurang mendukung.

Berbagai kemungkinan di atas, dipandang perlu dicari penyebab utama yang segera harus diatasi, diantaranya adalah tentang penerapan metode pembelajaran yang tepat dan hubungannya dengan tingkat kemampuan beradaptasi terhadap penguasaan keterampilan baru (ME) terhadap penguasaan keterampilan smash kedeng dalam permainan sepak takraw. Usaha untuk meningkatkan penguasaan keterampilan smash kedeng dalam permainan sepak takraw melalui pengajaran dikenal beberapa metode mengajar antara lain: metode latihan, metode demontrasi, metode ceramah, metode praktik bagian dan keseluruhan. Penelitian ini akan berkonsentrasi pada penerapan metode bagian dan metode keseluruhan dengan tingkat $M E$ yang berbeda. 


\section{METODE}

Penelitian ini dilaksanakan di SMPN 4 Kubutambahan Singaraja, Bali. Penelitian dilaksanakan dengan frekuensi 3 kali seminggu dan 90 menit setiap kali pertemuan. Populasi dalam penelitian adalah siswa putra SMPN 4 Kubutambahan Singaraja pada tahun pelajaran 2012/2013, terdiri dari empat kelas dan jumlah siswa putranya adalah 124 orang. Sampel dalam penelitian 40 orang. Teknik pengambilan sampel menggunakan proporsional random sampling. yaitu suatu teknik pengambilan sampel secara acak dengan memberikan kesempatan yang sama dari masing-masing anggota populasi sebagai sampel, yang jumlahnya disesuaikan dengan jumlah anggota subyek yang ada dalam masingmasing kelompok (Suharsini Arikunto, 2003 : 126-128). Sejumlah siswa yang memenuhi ketentuan terdapat 40 orang, selanjutnya diukur tingkat $M E$-nya untuk mengetahui siswa yang memiliki ME tinggi dan rendah. Berdasarkan skor dari hasil pengukuran kemudian dihitung T-skornya dan selanjutnya di rangking. Berdasarkan sampel penelitian adalah 20 orang dengan skor tinggi dan 20 siswa dengan skor rendah. Kemudian dari 20 orang yang terpilih dalam setiap taraf, ditetapkan secara undian ke dalam kedua kelompok metode pembelajaran yaitu metode praktik keseluruhan (whole practice method) dan metode praktik bagian (part practice method). Jenis penelitian adalah eksperimen lapangan, ini didasarkan pada variabel serta tujuan yang ingin dicapai dalam penelitian. Kerlinger (2002 : 645) menyatakan bahwa eksperimen lapangan adalah kajian dalam suatu nyata (realitas), dengan memanipulasi satu variabel bebas atau lebih dalam kondisi yang dikontrol dengan cermat oleh pembuat eksperimen sejauh yang dimungkinkan oleh situasinya. Desain yang dipergunakan dalam penelitian ini adalah faktorial $2 \times 2$ (Sudjana, 2002 : 154). Penelitian ini melibatkan dua variabel bebas (independent) dan satu variabel terikat (dependent). Variabel bebas terdiri dari satu variabel manipulatif dan satu variabel atributif sedangkan variabel terikat dalam penelitian ini adalah keterampilan teknik dasar smash kedeng dalam permainan sepak takraw. Dalam pelaksanaan penelitian dan analisis data, seluruh data tingkat ME siswa yang diperlukan dikumpulkan dengan menggunakan IOWA Brace Test, sedangkan data keterampilan teknik dasar bermain sepak takraw dikumpulkan dengan tes keterampilan dasar sepak takraw (Sulaiman, 2009: 90). Data tentang ME diperoleh dengan menggunakan IOWA Brace Test. Hasil dari tes tersebut digunakan untuk mengetahui tingkat ME siswa, yang merupakan kesanggupan masing-masing individu melakukan gerakan dengan benar. Tim peneliti terlebih dahulu menjelaskan aturan kepada siswa (testee) serta memberi contoh gerakan yang harus dilakukan sebelum tes dilaksanakan. Hal tersebut dimaksud untuk mempermudah pemahaman dan mencegah terjadinya kesalahan gerakan siswa (testee) melakukan serangkaian gerakan tes ME. Telah dijelaskan sebelumnya bahwa terdapat 21 butir tes ME dan diberikan sebanyak dua kali kesempatan untuk melakukan gerakan. Dari pengumpulan hasil tes tersebut, maka dapat ditentukan (1) testee yang memiliki tingkat $M E$ tinggi, dan (2) testee yang memiliki tingkat $M E$ rendah. Dasar untuk menentukan batas tinggi rendahnya tingkat $M E$ adalah dari perhitungan rangking dari data yang terkumpul. Data keterampilan teknik dasar bermain sepak takraw dikumpulkan dengan tes keterampilan dasar sepak takraw (Sulaiman, 2009: 90). Dalam penelitian ini teknik analisis data yang digunakan untuk menguji hipotesis dengan menggunakan teknik Analisis Varians (ANAVA).

\section{HASIL DAN PEMBAHASAN}

Objek dalam penelitian ini adalah perbedaan penguasaan keterampilan dasar smash kedeng dalam permainan sepak takraw sebagai hasil treatment antara 
penerapan metode praktik keseluruhan dan bagian dengan mempertimbangkan tingkat ME siswa. Penelitian ini menggunakan rancangan factorial research dengan menggunakan anava dua jalur (Glass and Hopskins, 1984 : 272-301). Eksperimen faktorial adalah eksperimen yang hampir semua atau semua taraf pada sebuah faktor dikombinasikan atau disilangkan dengan semua taraf tiap faktor lainnya yang ada dalam eksperimen (Sudjana, 1989 : 148). Berdasarkan rasional tersebut, maka data dalam penelitian ini dapat dikelompokkan menjadi : (1) kelompok $A_{1}$ yaitu kelompok siswa yang diajar dengan metode praktik keseluruhan, (2) kelompok $\mathrm{A}_{2}$ yaitu kelompok siswa yang diajar dengan metode praktik bagian, (3) kelompok $B_{1}$ yaitu kelompok siswa yang memiliki tingkat $M E$ tinggi, (4) kelompok $B_{2}$ yaitu kelompok siswa yang memiliki tingkat ME rendah, (5) kelompok $A_{1} B_{1}$ yaitu kelompok siswa yang memiliki tingkat ME tinggi yang diajar dengan metode praktik keseluruhan, (6) kelompok $A_{1} B_{2}$ yaitu kelompok siswa yang memiliki tingkat ME rendah yang diajar dengan metode praktik keseluruhan, (7) kelompok $A_{2} B_{1}$ yaitu kelompok siswa yang memiliki tingkat $\mathrm{ME}$ tinggi yang diajar dengan metode praktik bagian, dan (8) kelompok $A_{2} B_{2}$ yaitu kelompok siswa yang memiliki tingkat $M E$ rendah yang diajar dengan metode praktik bagian.

\section{Uji Prasarat Analisis Uji Normalitas Data}

Uji normalitas data dilakukan pada gaint score data tes smash kedeng dalam permainan sepak takraw. Dari hasil uji normalitas dengan instrument uji OneSample Kolmogrov-smirnov-test dengan bantuan program komputer SPSS 10,0 pada taraf signifikansi (a) 0,05 diperoleh nilai signifikansi hitung untuk semua data yang diuji lebih besar dari a (sig > 0,05), dengan demikian semua data berdistribusi normal.

\section{Uji Homogenitas Varians}

Uji homogenitas data dilakukan terhadap data gaint score tes smash kedeng dalam permainan sepak takraw menggunakan instrument uji lavene dengan bantuan program komputer SPSS 10,0 pada taraf signifikansi (a) 0,05. Dari hasil uji didapatkan nilai signifikansi hitung untuk kedua data tersebut lebih besar dari pada $\alpha$ (Sig > 0,05), dengan demikian data yang di uji berasal dari data dengan variansi homogen.

\section{Pengujian Hipotesis}

Dalam pengujian hipotesis secara keseluruhan digunakan analisis varians dua jalur pada taraf signifikansi 5\% dengan kriteria pengujian yang digunakan adalah: 1. Apabila antar tingkatan faktor pada metode pembelajaran (antar kolom) nilai $F_{\text {hitung }}$ lebih besar daripada nilai $F_{\text {tabel }}\left(F_{h}>\right.$ $F_{t}$ ), dinyatakan terdapat perbedaan yang signifikan menurut metode pembelajaran. 2.Apabila antar tingkatan faktor ME (antar baris) nilai $F_{\text {hitung }}$ lebih besar daripada nilai $F_{\text {tabel }}\left(F_{h}>F_{t}\right)$, dinyatakan terdapat perbedaan yang signifikan menurut tingkat ME. 3. Bilamana pada pengaruh interaksi nilai $F_{\text {hitung }}$ lebih besar dari pada nilai $F_{\text {tabel }}$ $\left(F_{h}>F_{t}\right)$, dinyatakan terdapat pengaruh interaksi yang signifikan antara metode praktik dengan tingkat ME.

Berpijak dari kriteria pengujian hipotesis yang sudah diuraikan sebelumnya, diperoleh hasil uji hipotesis secara keseluruhan dengan menggunakan analisis varians dua jalur dengan bantuan SPSS 10,0, dapat dilihat harga-harga dari $F_{\text {hitung }}$ antar tingkatan faktor pada metode pembelajaran (antar kolom), $F_{\text {hitung }}$ antar tingkatan faktor pada tingkat ME (antar baris), dan $F_{\text {hitung interaksi antara metode }}$ praktik dengan tingkat ME dalam pengaruhnya terhadap keterampilan dasar smash kedeng dalam permainan sepak takraw.

Berdasarkan atas ringkasan tabel analisis varians dua jalur pada Tabel 4.4 tersebut, dapat ditemukan bahwa: Untuk 
antar kolom, diperoleh harga $F_{(A) h i t u n g}$ $=22,330$, sedangkan harga $F_{\text {tabel }}$ pada $\mathrm{db}_{\mathrm{A}}=$ 1 dan $\mathrm{db}_{\mathrm{D}}=36$ untuk taraf signifikansi $5 \%=$ 4,11. Ini berarti bahwa $F_{\text {hitung }}$ lebih besar dari pada $F_{\text {tabel }}$ pada taraf signifikansi $5 \%\left(\mathrm{~F}_{\mathrm{h}}=\right.$ $\left.22,330>F_{t(1 ; 36 ; 0,05)}=4,11\right)$. Dengan demikian, hipotesis nol $\left(\mathrm{H}_{0}\right)$ yang menyatakan secara keseluruhan tidak terdapat perbedaan penguasaan keterampilan dasar smash kedeng sepak takraw yang signifikan antara kelompok siswa yang memperoleh metode praktik keseluruhan dan kelompok siswa yang memperoleh metode praktik bagian, ditolak. Sebaliknya hipotesis alternatif $\left(\mathrm{H}_{1}\right)$ yang menyatakan bahwa terdapat perbedaan penguasaan keterampilan dasar smash kedeng dalam permainan sepak takraw yang signifikan antara kelompok siswa yang memperoleh metode praktik keseluruhan dan kelompok siswa yang memperoleh metode praktik bagian, diterima. Dengan demikian dapat disimpulkan bahwa secara keseluruhan terdapat perbedaan penguasaan keterampilan dasar smash kedeng dalam permainan sepak takraw yang signifikan antara kelompok siswa yang memperoleh metode praktik keseluruhan dan kelompok siswa yang memperoleh metode praktik bagian.

1. Untuk antar baris, diperoleh harga ${ }_{F(B) h i t u n g}$ $=17,876$ dan harga Ftabel pada $d_{\mathrm{bB}}=1$ dan $\mathrm{d}_{\mathrm{bD}}=36$ untuk taraf signifikansi $5 \%$ sebesar 4,11. Hal ini berarti, bahwa harga Fhitung lebih besar dari pada harga Ftabel pada taraf signifikansi $5 \%(\mathrm{Fh}=17,876>$ $\mathrm{Ft}(1 ; 36 ; 0,05)=4,11$. Dengan demikian, hipotesis nol (но) yang menyatakan secara keseluruhan tidak terdapat perbedaan penguasaan keterampilan dasar smash kedeng dalam permainan sepak takraw yang signifikan antara kelompok siswa yang memiliki tingkat ME tinggi dan kelompok siswa yang memiliki tingkat ME, ditolak. Sebaliknya hipotesis alternatif $\left.{ }_{\mathrm{H} 1}\right)$ yang menyatakan bahwa terdapat perbedaan penguasaan keterampilan dasar smash kedeng dalam permainan sepak takraw yang signifikan antara kelompok siswa yang memiliki tingkat ME tinggi dan kelompok siswa yang memiliki tingkat ME rendah, diterima. Dengan demikian dapat disimpulkan bahwa terdapat perbedaan penguasaan keterampilan dasar smash kedeng dalam permainan sepak takraw yang signifikan antara kelompok siswa yang memiliki tingkat ME tinggi dan kelompok siswa yang memiliki tingkat ME rendah. Dengan memperhatikan skor rata-rata yang diperoleh, kelompok siswa yang memiliki tingkat ME tinggi lebih baik dibandingkan dengan kelompok siswa yang memiliki tingkat ME rendah dalam penguasaan keterampilan dasar smash kedengdalam permainan sepak takraw.

2. Untuk interaksi, harga $F_{A \times B(\text { hitung })}=4,34$ dan harga $F_{\text {tabel }}$ pada $\mathrm{db}_{\mathrm{AB}}=1$ dan $\mathrm{db}_{\mathrm{D}}=$ 36 , untuk taraf signifikasi $5 \%$ sebesar 4,11. Hal ini berarti nilai $F_{A \times B(\text { hitung) }}$ lebih besar dari pada nilai $F_{\text {tabel }}$ pada taraf signifikansi $5 \% \quad\left(F_{A \times B}\right.$ hitung $=4,34>$ $\left.F_{t(1 ; 36 ; 0,05)}=4,11\right)$. Dengan demikian, hipotesis nol $\left(\mathrm{H}_{0}\right)$ yang menyatakan tidak terdapat interaksi antara metode pembelajaran dan tingkat ME terhadap penguasaan keterampilan dasar smash kedeng dalam permainan sepak takraw, ditolak. Sebaliknya, hipotesis alternatif $\left(\mathrm{H}_{1}\right)$ yang menyatakan terdapat interaksi antara metode pembelajaran dan tingkat ME terhadap penguasaan keterampilan dasar smash kedeng bermain sepak takraw, diterima. Dengan demikian dapat disimpulkan bahwa terdapat interaksi antara metode pembelajaran dan tingkat ME terhadap penguasaan keterampilan dasar smash kedeng dalam permainan sepak takraw.

\section{PEMBAHASAN}

1. Perbedaan Pengaruh Metode Praktik Keseluruhan dan Praktik Bagian Terhadap Penguasaan Keterampilan Teknik Dasar Smash Kedeng dalam Permainan Sepak Takraw 
Berdasarkan pengujian hipotesis pertama ternyata ada perbedaan pengaruh yang signifikan antara kelompok siswa yang mendapatkan metode praktik keseluruhan dan kelompok siswa yang mendapatkan metode praktik bagian terhadap penguasaan keterampilan teknik dasar smash kedeng dalam permainan sepak takraw Pada Siswa Putra SMPN 4 Kubutambahan. Apabila dilihat dari masingmasing nilai mean kelompok siswa yang mendapatkan metode praktik keseluruhan memiliki hasil yang lebih baik daripada kelompok siswa yang mendapatkan metode praktik bagian. Hal ini disebabkan karena penerapan metode praktik keseluruhan dalam pembelajaran keterampilan teknik dasar smash kedeng dalam permainan sepak takraw sangat sesuai dengan karakteristik dari materi itu sendiri dan juga karakteristik perkembangan dari siswa.

Karakteristik dari permainan sepak takraw (smash kedeng) adalah bentuk olahraga yang merupakan perpaduan dari beberapa jenis olahraga, seperti: senam, beladiri, sepakbola dan basket (Sulaiman, 2008 : 73). Unsur-unsur gerakan dapat dilihat ketika seorang pemain sepak takraw melakukan smash kedeng. Gambaran gerakan-gerakan yang dilakukan oleh pemain sepak takraw memerlukan keterampilan fisik teknik yang tinggi. Cabang olahraga sepak takraw (smash kedeng) memerlukan berbagai komponen fisik terutama: kekuatan, kecepatan, kelenturan, keseimbangan, sehingga setiap pemain dituntut memiliki kondisi yang prima sehingga dapat menjalin sinergi gerak dengan pemain lainnya dalam satu regu sepak takraw. Karakteristik siswa putra SMPN 4 Kubutambahan (masa muda) adalah masa dimana perubahan tubuh dan juga sistem fisiologis sangat mempengaruhi pencapaian kemampuan suatu gerak dan bisa menghadirkan suatu mekanisme dalam suatu proses penuaan (Gallahue dan Ozmun, 1988 : 411). Pada masa ini perubahan karena faktor pertumbuhan atau masa adolesensi yang mengalami perubahan yang sangat cepat. Pada masa ini terjadi peningkatan kemampuan yang dihasilkan atau disebabkan oleh proses pertumbuhan yang menyertai bertambahnya usia, dan juga dipengaruhi dari pengalaman dan latihan (Sugiyanto, 1998 : 210). Penererapan metode praktik keseluruhan memberikan Pengertian yang mendalam (insight) kepada siswa, siswa dapat mengamati dan menempatkan setiap bagian dari gerakan berkaitan dengan keseluruhan, bagian-bagian dari gerakan dipelajari tidak lepas dari konteks keseluruhan, dan juga siswa aktif terlihat dalam pemecahan masalah (Engkos Kosasih, 1997 : 46). Sehingga memberikan kesempatan gerak yang seluas-luasnya kepada siswa dalam proses pembelajaran teknik dasar bermain sepak takraw.

Dalam pembelajaran yang menggunakan metode praktik keseluruhan, proses pembelajaran keterampilan teknik dasar smash kedeng dalam permainan sepak takraw diajarkan secara utuh mulai dari tahap awal sampai tahap akhir yang menjadi satu kesatuan unit rangkaian gerakan, dimana rangkaian gerakan tidak terputus, tanpa memilah-milah rangkaian gerakan atau komponen gerak.

Keterampilan teknik dasar smash kedeng harus dipelajari secara keseluruhan karena keterampilan teknik dasar smash kedeng dalam permainan sepak takraw mempunyai tingkat organisasi gerakan yang tinggi atau keeratan hubungan antar bagian gerakan tinggi. Suatu keterampilan gerak yang mempunyai tingkat kerumitan hubungan antara bagian-bagian gerakan, atau yang disebut tingkat organisasi gerakan sedang maka lebih cocok menggunakan metode praktik keseluruhan sedangkan apabila suatu keterampilan gerak mempunyai tingkat keragaman unsurunsur gerakan yang membentuk gerakan keseluruhan atau disebut tingkat kompleksitas gerakan tinggi lebih cocok menggunakan metode praktik bagian (Sugiyanto dan Sujarwo, 1994 : 369; LANKOR, 2007 : 99). Disamping itu 
keterampilan teknik dasar smash kedeng dalam permainan sepak takraw termasuk permainan yang sederhana. Metode praktik keseluruhan akan memberikan keuntungan yang maksimal jika yang dipelajari itu gerakan yang sederhana (Rusli Lutan, 1988 : 411).

2. Perbedaan Penguasaan Keterampilan Teknik Dasar Smash Kedeng dalam Permainan Sepak Takraw Antara yang Memiliki ME Tinggi dan Rendah

Berdasarkan pengujian hipotesis yang kedua ternyata terdapat perbedaan penguasaan keterampilan dasar smash kedeng dalam permainan sepak takraw yang signifikan pada siswa putra SMPN 4 Kubutambahan, dimana hasil penguasaan keterampilan teknik dasar smash kedeng dalam permainan sepak takraw kelompok siswa yang memiliki tingkat $M E$ tinggi cenderung lebih baik dibanding dengan kelompok siswa dengan $M E$ rendah.

$M E$ adalah suatu istilah yang menunjukkan kapasitas seseorang mempelajari keterampilan yang sifatnya baru dalam waktu yang cepat dengan kualitas yang baik. Kemampuan $M E$ merupakan kemampuan yang mendasari pembentukan gerak keterampilan yang akan dilakukan. Penguasaan suatu keterampilan gerak merupakan sebuah proses pada seseorang yang mengembangkan seperangkat respons ke dalam suatu pola gerakan yang terkoordinasi, terorganisasi, dan terpadu dengan baik (Rusli Lutan, 1988 : 95). Kemampuan ME merupakan fundamental penting untuk mempelajari suatu keterampilan gerak. Dalam mempelajari suatu keterampilan gerak tertentu diperlukan jangka waktu tertentu yang sangat dipengaruhi oleh kompleksitas gerakan yang akan dipelajari dan juga $M E$ yang dimiliki oleh siswa. Kemampuan $M E$ merupakan dasar dalam pembentukan keterampilan gerak, termasuk saat mempelajari keterampilan teknik dasar smash kedeng dalam permainan sepak takraw.

$\begin{array}{cc}\text { Kualitas } & \text { potensial } M E \text { akan } \\ \text { memberikan } & \text { gambaran mengenai }\end{array}$ kemampuan seseorang dalam mempelajari gerakan-gerakan yang baru dengan mudah. Makin tinggi tingkat potensial MEnya, berarti derajat penguasaan terhadap gerakangerakan baru makin mudah (Kirkendall, et.al, 1987 : 131, Rusli Lutan, 1988 : 119). Sehingga apabila seseorang memiliki tingkat $M E$ yang tinggi maka dapat dengan mudah, cepat menguasai keterampilan teknik dasar smash kedeng dalam permainan sepak takraw dengan kuantitas dan kualitas gerakan yang baik daripada orang yang memiliki tingkat $M E$ yang rendah. Disamping itu kemampuan ME merupakan dasar pembentukan keterampilan gerak, sehingga dalam belajar keterampilan teknik dasar bermain sepak takraw akan lebih cepat dikuasai jika didukung dengan $M E$ yang tinggi. Karakteristik dari smash kedeng dalam permainan sepak takraw adalah bergerak ke segala arah, melangkah, melompat sehingga diperlukan komponenkomponen fisik yang prima. Komponen itu meliputi kecepatan, kekuatan, kelenturan, daya ledak, kelincahan dan juga keseimbangan, yang sangat dibutuhkan seorang pemain sepak takraw. ME yang tinggi dapat menunjang keberhasilan dalam belajar keterampilan teknik dasar bermain sepak takraw, karena siswa yang memiliki ME tinggi akan lebih bisa mengontrol gerakan-gerakan yang dilakukan sehingga lebih mudah dan cepat menguasai suatu gerakan keterampilan teknik dasar bermain sepak takraw dengan kuantitas dan kualitas gerakan yang baik dibanding siswa yang memiliki $M E$ rendah.

3. Interaksi Antara Metode Pembelajaran dan Tingkat ME Terhadap Penguasaan Keterampilan Dasar Smash kedeng Bermain Sepak Takraw

Dari hasil analisis data tentang interaksi antara metode pembelajaran dan tingkat ME terhadap keterampilan dasar 
smash kedeng bermain sepak takraw pada siswa putra SMPN 4 Kubutambahan, dapat disimpulkan bahwa tidak terdapat interaksi antara metode pembelajaran dan tingkat $M E$ terhadap penguasaan keterampilan dasar smash kedeng dalam permainan sepak takraw. Pada kelompok siswa yang memiliki tingkat $M E$ tinggi, penguasaan keterampilan dasar smash kedeng dalam permainan sepak takraw kelompok siswa yang mengikuti metode praktik keseluruhan lebih baik dibandingkan kelompok siswa yang mengikuti metode praktik bagian. Sedangkan pada kelompok siswa yang memiliki tingkat $M E$ rendah, penguasaan keterampilan dasar bermain sepak takraw kelompok siswa yang mengikuti metode praktik keseluruhan lebih baik dibandingkan kelompok siswa yang mengikuti metode praktik bagian.

\section{SIMPULAN DAN SARAN}

Berdasarkan hasil analisis data dan pembahasan, maka dalam penelitian ini dapat disimpulkan sebagai bahwa: 1)Ada perbedaan pengaruh yang signifikan antara metode praktik keseluruhan dan metode praktik bagian terhadap penguasaan keterampilan dasar smash kedeng sepak takraw, dimana secara keseluruhan metode praktik keseluruhan lebih baik dari metode bagian. 2) Ada perbedaan penguasaan keterampilan dasar smash sepak takraw yang signifikan antara kelompok yang memiliki tingkat ME tinggi dan kelompok yang memiliki tingkat ME rendah, dimana kelompok siswa yang memiliki tingkat $\mathrm{ME}$ tinggi lebih baik dibandingkan dengan kelompok mahasiswa yang memiliki tingkat $M E$ rendah. 3) Ada pengaruh interaksi antara metode pembelajaran dan tingkat $\mathrm{ME}$ terhadap penguasaan keterampilan dasar smash sepak takraw. Pada kelompok siswa yang memiliki tingkat ME tinggi, penguasaan keterampilan dasar bermain sepak takraw kelompok siswa yang mengikuti metode praktik keseluruhan lebih baik dibandingkan kelompok siswa yang mengikuti metode praktik bagian. Sedangkan pada kelompok siswa yang memiliki tingkat ME rendah, penguasaan keterampilan dasar smash kedeng sepak takraw kelompok siswa yang mengikuti metode praktik bagian lebih baik dibandingkan kelompok mahasiswa yang mengikuti metode praktik keseluruhan.

Kepada para guru pendidikan jasmani olahraga dan kesehatan, dalam mengajar teknik dasar smash kedeng sepak takraw putra dapat menggunakan metode praktik keseluruhan dan juga metode praktik bagian, yang disesuaikan dengan tingkat ME.

\section{DAFTAR PUSTAKA}

Adang Suherman. 2000. Dasar-dasar Penjaskes. Jakarta: Dirjen Depdikbud.

Azhari Taga. 2008. Effect of Diameter on the Aerodynamics of Sepaktakraw Balls.

Malaysia:http://www.worldacademicunion.co $\mathrm{m} /$ journal/SSCI/SSClvol02no02paper 07.pdf [Downloaded 4-1-2012]

Bompa. 2000. Total Training for Young Champion. Champign: Human Kinetics.

Hergenhahn B R dan Olson Mattew H. Teori Belajar. Diterjemahkan dari Theories Of Learning oleh Tri Wibowo B S. Jakarta. Kencana.

Husdarta. 2009. Manajemen Pendidikan Jasmani. Bandung. Alfabeta.

Jawis, MN, Singh, R., Singh, HJ, Yassin, MN, Khanna, GL. 2006. Anthropometric and physiological profiles of sepak takraw players. Malaysia http://bjsm.bmj.com/content/ 39/11/825.[Downloaded 2-1-2012]

Johnson, Barry L. and Jack K. Nelson. 1986. Pratical Measurement For Evaluation in Physical Education $4^{\text {nd }}$ ed. Macmillan Publishing Company.

Kirkendall, Gruber and Johson. 1987. Measurement and Evaluation for Physical Educators $2^{\text {nd }}$ ed. 
Champaign: Human Kinetics Publishers, Inc.

Kerlinger, Fred N. 2002. Asas-asas Penelitian Behavioral (Edisi terjemahan oleh $\mathrm{R}$ Simatupang). Bandung: Gajah Mada University Pres.

Magill, Richard A. 2001. Motor Learning: Consepts and Applications $6^{\text {th }}$ ed. New York: Mc. Graw-Hill Companies.

Morrow JR dkk. 2005. Measurement And Evaluation in Human Performance. Kanada: Human Kinetics.

Nurhasan.2000. Tes dan penggukuran pendidikan olahraga. Jakarta: FPOK UPI

------, 2001. Tes Pengukuran dalam Pendidikan Jasmani: Prinsip-Prinsip dan Penerapannya. Jakarta: Depdiknas Ditjen Pendidikan Dasar dan Menengah bekerjasama Direktorat Jenderal Olahraga.

Pate, Russell R., Cleneghan, Bruce Mc and Rottela, Robert. 1984. Scientific Foundations of Coaching. New York: Sounders Colege Publishing.

PB. PERSETASI. 1999. Mari Bermain Sepak Takraw. Jakarta: PB PERSETASI

PB PSTI. 2007. Peraturan Permainan Peraturan Perwasitan dan Peraturan pertandingan Sepak Takraw. Jakarta: PB PSTI.

Rahantoknam, B.E. 1988. Belajar Teori dan Aplikasi dalam Pendidikan Jasmani dan Olahraga. Jakarta: Depdikbud.

Ratinus Darwis dan Penghulu Basa. 1992. Olahraga Pilihan Sepak Takraw. Jakarta: Depdikbud Dirjen Dikti.

Rusli Lutan. 1988. Belajar Keterampilan motorik: Pengantar Teori dan Metode. Jakarta: Departemen Pendidikan dan Kebudayaan Direktorat Jenderal
Pendidikan
Tinggi
Proyek
Pengembangan Lembaga
Pendidikan Tenaga Kependidikan.

Simanjuntak, Victor G. 2009. Pendidikan Jasmani dan Kesehatan. Jakarta: Dirjen Dikti Depdiknas.

Siswandari. 2009. Statistika Computer Based. Surakarta: Sebelas Maret University Press.

Sudrajat Prawirasaputra. 2000. Sepak Takraw. Jakarta: Depdiknas Dirjen Pendidikan Dasar dan Menengah. Jakarta

Sudjana. 2005. Metode Statistika. Ed. Ke 6. Bandung: Penerbit Tarsito.

Sugiyanto. 1999. Belajar Gerak dan Perkembangan Gerak Manusia BPK. Surakarta: Departemen Pendidikan dan Kebudayaan Republik Indonesia.

Sugiyanto dan Sudjarwo. 1994. Perkembangan dan Belajar Gerak Buku II: Jakarta: Depdikbud.

Sugiyono. 2008. Statistika untuk Penelitian.Cetakan ketigabelas. Bandung: CV Alvabeta.

Suharsini Arikunto. 2003. Manajemen Penelitian. Jakarta: Rineka Cipta.

2005. Manajemen Penelitian.ed revisi. Jakarta: Rineka Cipta.

Sukintaka. 2004. Teori Pendidikan Jasmani.Cetakan Pertama. Bandung:Yayasan Nuansa Cendekia.

Sulaiman. 2007. Permainan Sepak Takraw. http://sulaimanfikunnes.blogspot.com/2007/10/sepak -takraw.html [Downloaded 2-11-2009]. 2008. Sepak Takraw: Pedoman Bagi Guru Olahraga, Pembina, Pelatih, dan Atlet. Semarang: UNNES Pres.

Widiastuti. 2011. Tes dan Pengukuran Olahraga. Jakarta: PT Bumi Timur Jaya. 